\title{
Kerajinan Ukiran Kayu Di Palembang
}

\author{
AJI WINDU VIATRA ${ }^{1}$, RETIKA WISTA ANGGRAINI ${ }^{2}$ \\ Desain Komunikasi Visual, Fakultas Ilmu Pemerintahan dan Budaya, \\ Universitas Indo Global Mandiri, Palembang \\ E-mail :w1ndoe@yahoo.com,retika19@gmail.com
}

\begin{abstract}
Seni ukiran Palembang telah dikenal luas, seni kerajinan ukir kayu yang lazim disebut Ukiran Palembang. Adapun sentra industri seni kerajinan ukiran kayu Palembang berada di Kampung 19 Ilir, Kecamatan Bukit Kecil, sebelah Barat Masjid Agung Palembang. Kampung 19 Ilir, memproduksi berbagai bentuk perabotan, alat-alat rumah tangga, dan hiasan rumah dengan ukiran kayu khas Palembang. Kegiatan mengukir di Palembang sebelumnya memiliki hubungan erat dengan rumah tradisional adat Palembang, yakni rumah Bari atau rumah Limas. Rumah tradisional yang saat ini masih digunakan oleh masyarakat Sumatera Selatan, khususnya di Palembang dengan segala perlengkapan rumah tangganya. Pertumbuhan ukiran kayu Palembang mengalami pasang surut dengan kondisi sosial dan ekonomi di wilayah tersebut. Seni kerajinan ukiran kayu ini hanya diproduksi oleh keluarga-keluarga tertentu saja, masih banyak masyarakat Palembang dan para perajin beralih mengandalkan penghasilan ekonomi dengan mencari profesi lain. Perubahan yang terjadi pada proses pengolahan bahan kayu yang semakin sulit digunakan, kreasi motif ukiran, dan teknik pengukiran telah bercampur dengan daerah lain seperti Jepara, dan negara luar India, Eropa dan China. Akulturasi ragam hias ini telah menghasilkan suatu bentuk, gaya dan cita rasa baru menambah khasanah ukiran kayu Palembang. Kajian utama penelitian ini dititik beratkan pada kontinuitas, perubahan dan analisis ragam hias pada motif ukiran kayu. Kajian ini menggunakan pendekatan multidisplin, yakni pendekatan sosiologi, dan estetika. Metode penelitian yang digunakan adalah metode kualitatif, dengan analisis deskriptif analitik. Penelitian ini bertujuan menganalisis dan mengidentifikasi perkembangan seni kerajinan ukiran kayu Palembang terhadap kehidupan masyarakat, terutama bagi pelaku budaya tersebut, mengkaji terjadinya perubahan dan perkembangan bentuk, motif ragam hias seni kerajinan ukiran kayu Palembang dan menggali pengetahuan secara mendalam mengenai kebudayaan Palembang.
\end{abstract}

Kata kunci : ukiran kayu, kontinuitas, ragam hias, motif ukiran, palembang

\section{Wooden Crafts At Palembang}

Woodcarving arts from Palembang are widely known and commonly referred ro Ukiran Palembang. The center of woodcarving art industry of Palembang is in Kampung 19 Ilir, District of Bukit Kecil, West of Palembang Grand Mosque. Kampung 19 Ilir, produces various forms of furniture, and home decoration with wooden carving typical of the Palembang style. Woodcarving arts from Palembang previously fostered a very close ralationship with the traditional homes of Palembang, known as the Bari or Limas houses. Bari or Limas houses are Traditional houses that are still used by the people of South Sumatra, especially in Palembang equipped with household accessories made in Palembang. The growth of Palembang woodcarving has experienced fluctuation relative to regional economic conditions Art craft woodcarving is continued only by certain families, as the economic situation of the region causes many craftsmen to search for employment in other industries and professions. Changes in wood processing procedures have caused materials to become increasingly difficult to use. Also, carving motive creations, and engraving techniques have been hybridized with other regions such as Jepara, and countries outside India, Europe and China. The acculturation of this decorative variety has resulted in new forms, styles and flavors adding to the treasures of Palembang woodcarvings. The research method used is qualitative method, with analytic descriptive analysis. This study aims to analyze and identify the development of wood craft art of Palembang to the life of the community, especially for the cultural actors, to examine the changes and the development of the shape, ornamental motive motifs of Palembang wood carving artwork and explore deep knowledge about Palembang culture.

Keywords : wood carving, continuity, decorative variety, motif engraving, palembang. 


\section{PENDAHULUAN}

Aneka ragam budaya berkesenian di Indonesia, aktifitas seni dan budaya dengan segala pola ragam kontinuitas merupakan salah satu pendukung suatu kebudayaan yang tentunya mempunyai arti penting dalam kehidupan suatu bangsa atau suku bangsa di Indonesia. seni kriya menjadi salah satu khasanah kekayaan yang tak ternilai. Keberadaan seni kriya sebagai salah satu cabang seni rupa, aplikasinya lebih kepada karya terapan. Karya seni kriya selain memiliki nilai fungsional juga memiliki fungsi estetis, tidak kalah dengan seni rupa murni. Awalnya kriya sebatas karya kerajinan tangan saja yang dapat dimanfaatkan nilai gunanya, seperti peralatan rumah tangga, instansi, perusahaan, pertanian, perkebunan, dan pembangunan. Namun perkembangannya pemahaman kriya tidak hanya sebatas nilai gunanya saja, akan tetapi sudah menuju kepada nilai- nilai estetika.

Menurut Prof. Dr. Seodarso Sp (2006:107) dikutip dari kamus besar bahasa Indonesia "Kriya adalah pekerjaan atau kerajinan tangan, perkataan kriya memang belum lama dipakai dalam bahasa Indonesia; perkataan kriya itu berasal dari bahasa Sansekerta yang dalam kamus Wojowasito diberi arti; pekerjaan; perbuatan, dan dari kamus Winter diartikan sebagai 'demel' atau membuat. Kriya berarti kerajinan atau dalam bahasa Inggris disebut craft. Seni kriya adalah cabang seni rupa yang sangat memerlukan keahlian kekriyaan (craftmanship) yang tinggi seperti ukir, keramik, dan anyam. Prof. SP. Gustami yang menguraikan bahwa; seni kriya merupakan warisan seni budaya yang adi luhung, yang pada zaman kerajaan di Jawa mendapat tempat lebih tinggi dari kerajinan. Seni kriya dikonsumsi oleh kalangan bangsawan dan masyarakat elit sedangkan kerajinan didukung oleh masyarakat umum atau kawula alit, yakni masyarakat yang hidup di luar tembok keraton. Seni kriya dipandang sebagai seni yang unik dan berkualitas tinggi karena didukung oleh craftmanship yang tinggi, sedangkan kerajinan dipandang kasar dan terkesan tidak tuntas.

Keterampilan kerajinan tersebut didukung oleh lingkungan budaya masyarakat yang kreatif sehingga dapat dihasilkannya produk-produk yang kreatif dan unik. Sebagai contoh, industri kerajinan dan furnitur (mebel) di Jepara merupakan sentra industri yang telah terbentuk sejak beberapa abad yang lalu. Seni kerajinan ukiran kayu dimiliki oleh hampir setiap daerah diseluruh pelosok negeri ini, antara lain Sumatera, Kalimantan, Sulawesi, Bali, dan Papua. Kajian ini secara regional dispesifikan dalam regional Suma-

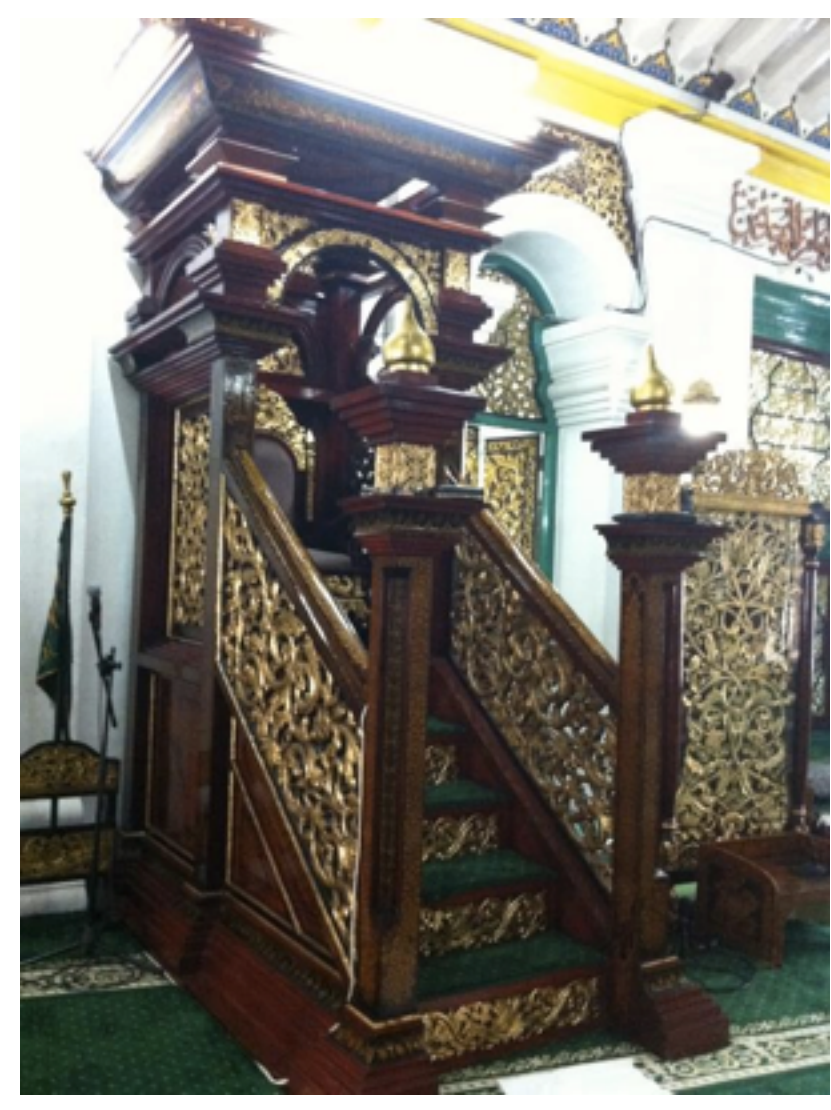

Gambar 1.

Produk seni kerajinan ukiran kayu di Masjid Agung Palembang, berupa Mimbar Masjid sebagai benda pakai.

(Sumber foto: Aji Windu Viatra, 2017)

tera Selatan, yaitu Palembang.

Seni ukiran Palembang dituliskan bahwa di Palembang telah dikenal luas sejak lama adanya seni ukir kayu yang lazim disebut Ukiran Palembang. Ukiran Palembang telah ada sejak zaman dahulu. Diperkirakan marak sejak zaman Kesultanan Palembang Darussalam. Sekitar tahun 1921, seni ukiran Palembang mulai dikenal dimana-mana terutama karena gaya ukirannya khas serta diberi warna keemasan (perada emas) di atas warna tepak (merah manggis). Tetapi seiring dengan waktu seni ukir Palembang, mengalami penurunan dalam hal sumber daya manusia (perajin), sumber daya alam (bahan kayu), dan hasil produksi kerajinan ukiran. Pengukir mulai berkurang, diperkirakan pada tahun lima puluhan sampai tujuh puluhan hanya ada beberapa keluarga perajin saja yang masih mengerjakan pekerjaan ini (Abdullah Salleh dkk, 1996: 5).

Para seniman perajin ukiran kayu Palembang tersebar di berbagai Kecamatan di Kota Palembang seperti di Kecamatan Bukit Kecil, Kecamatan Seberang Ulu 1, Kecamatan Seberang Ulu II, Kecamatan Ilir Barat 
I, Kecamatan Sukarami, dan Kecamatan Alang-Alang Lebar. Ditempat ini diproduksi berbagai macam ukiran kayu, seperti meja, kursi, lemari, lemari pengantin, puade (tempat pengantin bersanding), mimbar masjid dan alat- alat perabot rumah tangga yang terbuat dari kayu

Adapun industri seni kerajinan ukiran kayu cukup ramai oleh perajin adalah di Kampung 19 Ilir, sebelah Barat Masjid Agung Palembang, Kecamatan Bukit Kecil. Kampung 19 Ilir sebagai sentra industri kerajinan ukiran kayu, memproduksi berbagai bentuk ukiran khas Palembang yang sebagian besar hasilnya dipasarkan ke berbagai tempat di Pulau Jawa, selain yang dijual di toko mebel setempat. Hasil produksi ukiran ini banyak digemari dan dibeli oleh konsumen, sehingga para perajin ukiran kayu Palembang semakin bertambah jenis produk dan bentuk ragam hiasnya pun berkembang dengan model dan motif baru, tanpa meninggalkan unsur-unsur tradisional sebagai karakter khas ukiran Palembang.

Berdasarkan uraian di atas, penelitian ini akan menganalisis dan mengidentifikasi kontinuitas dan perubahan seni kerajinan ukiran kayu di kota Palembang, yang terkandung dalam beberapa bentuk motif ragam hias ukiran, bahan material, sosiologi para perajin ukiran kayu Palembang. Hal ini menarik untuk diungkapkan melalui penelitian ini, bagaimana mengkaji serta menganalisa keberlangsungan dan perkembangan kerajinan ukiran kayu Palembang.

\section{METODE PENELITIAN}

Metode yang dipergunakan dalam penelitian ini adalah metode penelitian kualitatif merupakan penelitian untuk mengumpulkan informasi mengenai gejala yang ada pada saat penelitian. Penelitian deskriptif tidak dimaksudkan untuk menguji hipotesis, tetapi menggambarkan apa adanya tentang suatu variable, gejala atau keadaan. Metode penelitian kualitatif digunakan dalam penelitian ini karena akan menjawab persoalan tentang ciri-ciri fenomena dengan tujuan mendeskripsikan dan memahami fenomena dari sudut pandang tertentu. Kajian kontinuitas seni kerajinan ukiran kayu Palembang akan diuraikan melalui pendekatan multidisplin, dengan mengembangkan analisis melalui perpaduan dua atau lebih disiplin ilmu (Gustami, 2004: 78). Pendekatan multidisiplin dalam penelitian ini sangat mungkin diterapkan, karena objek penelitian berhubungan langsung dengan budaya masyarakat. Pendekatan multidisiplin sangat dianjurkan dalam penelitian seni rupa (Soedarsono, 1999: 192). Penelitian ini akan mengkaji secara bersamaan keadaan sosial, seni budaya, teknologi pembuatan ukiran kayu, maupun pandangan hidupnya yang tercermin dalam motif dan rag- am hias ukiran kayu Palembang, hal tersebut diduga saling berkaitan erat satu sama lain atau saling mempengaruhi. Kemudian pendekatan estetika, yang digunakan untuk mengupas perubahan dan perkembangan desain ragam hias, bentuk, dan fungsi. Data yang terkait dengan pembahasan ini, maka diperoleh dengan menggunakan beberapa metode berikut :

\section{Populasi dan Sampel}

Populasi dalam penelitian ini adalah kegiatan-kegiatan yang dilakukan oleh para perajin dan hasil terapan ukiran kayu berupa produk furnitur yang cukup dominan diproduksi di kampung 19 Ilir Palembang. Ragam hias dengan motif-motif tertentu, yang akan dikaji dapat dilihat pada proses desain motif, bentuk, karakter, warna, teknik pengerjaan. Tetapi tidak semua populasi yang dijadikan sampel.

Karya seni kerajinan ukiran kayu yang dijadikan sampel adalah bagian- bagian bangunan rumah, benda pakai, dan benda hias dengan melihat perubahan dan perkembangan pola bahan dasar, warna, corak dan bentuk motifnya. Pembagian produk secara kelompok tersebut, akan kelihatan perubahan yang terjadi, sampel yang digunakan dengan beberapa kategori tersebut, diambil dengan alasan karena beberapa sampel itu sudah mewakili dari semua populasi yang ada, disini dapat terlihat perubahan dan perkembangan yang terjadi pada bentuk produk dan motif serta fungsi dari seni kerajinan ukiran kayu Palembang.

\section{Teknik Pengumpulan Data}

Beberapa teknik yang sesuai dengan tujuan dan bahan kajian penelitian ini dilakukan bersama secara simultan hal tersebut meliputi teknik observasi, wawancara, studi kepustakaan, dan studi dokumentasi yang terkait erat dengan objek penelitian itu sendiri. Teknik wawancara akan dilakukan secara terstruktur dan terpimpin dengan fokus pada penggalian informasi atas segala sesuatu mengenai ukiran kayu, khususnya mengenai motif-motif yang terdapat pada ukiran kayu Palembang. Narasumber atau informan dalam penelitian ini adalah pihak-pihak yang memiliki informasi dan memiliki kaitan erat dengan ukiran kayu Palembang.

\section{Tahap Analisa Data}

Penelitian ini akan dilaksanakan dalam beberapa tahap, yaitu: pertama, mencari semua data yang diperlukan mengenai ukiran kayu secara umum baik mengenai latar belakang dan perkembangannya maupun kekhasan motif dan ragam hias masing-masing. Kedua, mencari data-data kepustakaan mengenai lan- 
dasan teori yang mendukung dan dapat menjelaskan fenomena maupun proses kemunculan ukiran kayu Palembang dan perkembangannya. Ketiga, menganalisa corak ragam hias atau motif-motifkhusus yang terdapat dalam ukiran kayu Palembang, juga hal-hal mengenai teknik penciptaan, warna, gaya, sejarah, filosofi, simbol dan sebagainya guna menemukan keunikan dan kekhasan ukiran kayu Palembang, ditinjau dari sudut perupaan atau visualisasinya meliputi unsur garis, bentuk, rupa, warna tekstur, dan sejenisnya, juga material atau bahan yang dipakai serta fungsinya. Data yang perlu dianalisis menggunakan teknik analisis data yang meliputi langkah- langkah reduksi data dan verifikasi, penarikan kesimpulan guna memahami karakteristik seni kerajinan ukiran kayu Palembang.

\section{ANALISIS DAN INTERPRETASI DATA}

\section{Seni Kerajinan Ukiran Palembang}

Warga kota Palembang memanfaatkan lingkungan untuk menjalankan kehidupan, sehingga memunculkan aktifitas budaya dengan menciptakan kreasi sandang dan pangan. Pemanfaatan lingkungan tersebut dapat dilihat dari sumber daya alam Propinsi Sumatera Selatan yang memiliki kekayaan alam berupa pertanian, pertambangan, perhutanan, perikanan, dan perkebunan. Lingkungan dibidang perhutanan menghasilkan area hutan yang cukup luas dengan menghasilan kayu-kayu berkualitas yang terdiri dari berbagai jenis pohon, seperti pohon ulin, tembesu, medang, meranti, merawan, dan leban, sehingga pemanfaatan hasil kayu digunakan secara berkelanjutan untuk memenuhi kebutuhan hidup sandang dan pangan. Berbagai ragam kayu-kayu tersebut telah dimanfaatkan dalam bentuk seni kerajinan ukiran yang menawan, cindai, elok, unik, dan memiliki potensi yang sangat baik bagi daya pertumbuhan dunia usaha di perekonomian masyarakat. Hasil produk kerajinan ukiran, seperti meja, kursi, lemari, lemari pengantin, puade (tempat pengantin bersanding), mimbar masjid dan alat-alat perabot rumah tangga yang terbuat dari kayu.

Seni kerajinan ukir kayu Palembang memiliki hubungan erat dengan rumah tradisional adat Palembang, yakni rumah Bari atau rumah Limas. Rumah tradisional yang saat ini masih digunakan oleh masyarakat Sumatera Selatan, khususnya di Palembang dengan segala perlengkapan rumah tangganya. Aneka ragam perabotan yang ada berupa furniture atau alat-alat rumah tangga banyak yang terbuat dari kayu dengan ukirannya, dan berbagai peralatan yang kadang berfungsi sebagai hiasan rumah.

Diuraikan oleh Abdullah Saleh (1996: 5-7), Palem-

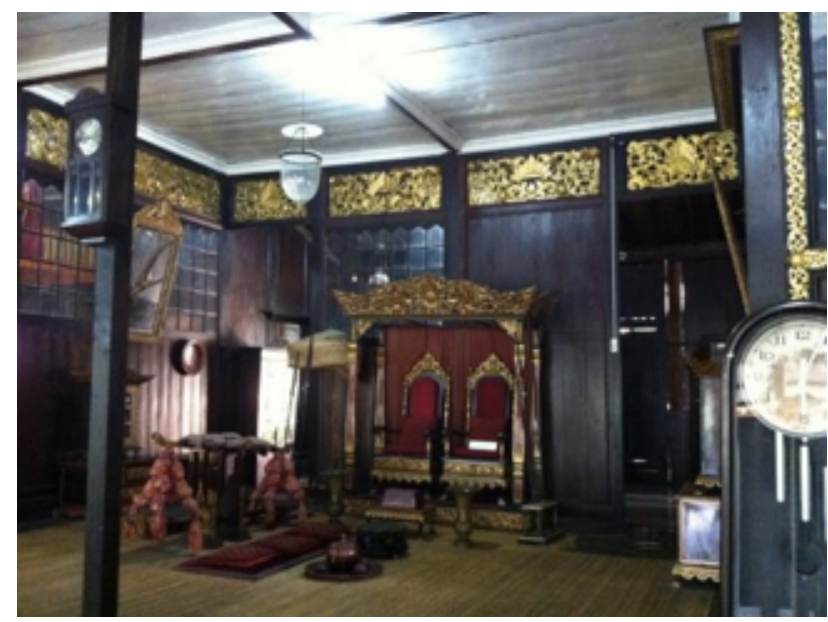

Gambar 2. Rumah Limas, Koleksi Museum Balaputra Palembang, Sumatera Selatan.

(Sumber Foto: Aji Windu Viatra, 2017).

bang telah dikenal secara luas memiliki seni kerajinan ukiran kayu di Nusantara, ukiran kayu Palembang telah hadir sejak zaman dahulu, diperkirakan sejak jaman kesultanan Palembang Darussalam. Kerajinan ini awalnya dikerjakan oleh kaum wanita, namun sejak tahun 1832 pekerjaan tersebut kurang diminati oleh kaum wanita dan berangsur dilakukan oleh kaum pria, berdasakan laporan Controleur J.C Banteburg yang memimpin utusan Palembang pada pameran seni ukir dalam rangka kongres Java Institute, Bandung, 1921. Saat 1921 itulah, seni kerajinan ukir kayu Palembang mulai dikenal di Nusantara dengan keunikan dan gaya ukiran yang memiliki warna keemasan diatas warna tepak atau merah manggis.

Saat ini, para perajin ukir kayu sudah banyak menyebar diberbagai kecamatan dan daerah, seperti kecamatan Ulu I,kecamatan Ulu II, kecamatan Ilir Barat I, dan kecamatan Ilir Barat II. Sekarang wilayah yang menjadi sentra pusat kerajinan ukir kayu Palembang berada di kecamatan Bukit Kecil, Kelurahan 19 Ilir, dekat dengan Masjid Agung Palembang, disentra ini memproduksi berbagai macam ukiran kayu, seperti : lemari, meja, rak, puade (tempat pengantin bersanding) atau pelaminan, kursi, dan perabotan rumah tangga. Hasil dari produksi ukiran kayu ini, banyak dipasarkan ke berbagai daerah pulau Jawa, Kalimantan, Sulawesi, dan Sumatera. Semakin berkembangnya produksi ukiran kayu tersebut, membuat banyak digemari oleh konsumen dari berbagai daerah Indonesia lainnya, maka para perajin makin bertambah banyak. Para perajin ukiran kayu semakin bersemangat mengembangkan macam-macam bentuk, model, dan motif-motif yang baru. Pemerintah tetap turut mendukung dalam upaya meningkatkan mutu dan pemasaran produk seni ukir kayu tersebut, dengan mengadakan pameran-pameran ditingkat Kotamadya, 
Propinsi dan Nasional.

\section{Ragam Hias Motif Ukiran Kayu Palembang}

Kesinambungan kerajinan seni ukir kayu Palembang yang telah menjadi tradisi kolektif masyarakat, dipengaruhi oleh kepedulian aneka ragam struktur sosial masyarakat pendukungnya untuk melestarikan seni kerajinan tersebut, dan yang telah menjadi produk budaya seni kerajinan dengan kontribusi kehidupan sosial dan ekonomi. Seni kerajinan digunakan sebagai benda budaya dan dikembangkan sebagai ungkapan rasa keindahan (Suwaji Bustami, 2003: 85). Pola kehidupan masyarakatnya sederhana dan mempunyai hubungan erat dengan lingkungan alamnya, karena sistem sosial budaya mempunyai hubungan timbal balik dengan lingkungan alam. Penciptaan berbagai motif untuk ukiran terbentuk dari berbagai bentuk yang ada di alam sesuai dengan falsafah "alam takambang jadi guru" (alam terkembang dijadikan guru) yang mengandung berbagai makna dalam pola kehidupan sosial budaya dalam masyarakat (A.A. Navis, 1984: 59).

Abad 7-10 masehi, jaman kerajaan Sriwijaya, seni ragam hias berkembang secara monumental yang memiliki makna simbolis menunjukan lambang dengan berbagai arti sebagai kebahagiaan, kemakmuran, kejayaan, kesuburan, keberuntungan, dan penolak bala. Ragam hias yang terdapat pada seni ukiran kayu Palembang berdasarkan sejarah masa Kesultanan mengartikan sebagai perlambang kebudayaan (Sukanti, 2012). Seni ragam hias ukiran kayu yang berkembang banyak dipengaruhi oleh kebudayaan asing yaitu terutama India dan China, bahkan pengaruh dari daerah lainnya seperti Jepara, Pekalongan, Solo, Mataram, dan Jogja. Pengaruh luar tersebut memberikan corak atau gaya yang beragam dalam kebudayaan Sumatera Selatan hingga saat ini.

Ragam hias ukiran kayu Palembang saat ini sangat dominan menggunakan motif yang diambil dari tumbuh-tumbuhan sebagai lambang kehidupan. Adapun jenis-jenis ragam hias berdasarkan motif ornamen berdasarkan bentuknya antara lain yaitu :

\section{Motif Tumbuh- Tumbuhan (Flora)}

Motif hias tumbuh-tumbuhan merupakan motif hias yang diambil dari berbagai jenis-jenis tumbuhan seperti bentuk daun, bunga dan batang. Kemudian distilir menjadi bentuk hiasan yang merambat bersulur yang bergerak kekanan dan kekiri. Hiasan yang menstilir tumbuh-tumbuhan sangat banyak dipergunakan, motif tumbuh- tumbuhan hampir menguasai setiap bentuk hiasan yang dibuat di Nusantara, seperti batu candi, keramik, batik, kain tenun, perabotan rumah tangga, dan barang kerajinan lainnya. Secara umum, berbagai motif ukiran itu dikategorikan kedalam tiga kelompok induk dasar ukiran, yaitu kelompok Suluran Daun Pakis, kelompok Bunga- bungaan, dan kelompok Pucuk Rebung.

\section{Motif Alam}

Motif alam merupakan pola gambar corak yang agak mendekati bentuk alam seperti awan, bintang, bulan, dan matahari. adalah ukiran bintang-bintang. Motif alam ini tidak banyak dipergunakan pada ukiran Palembang. Bentuk-bentuk alam ini hanya menyerupai alam dengan makna simbolis sesuai dengan variasi polanya. Pola dasar motif alam berupa garis- garis lembut dan lengkung, cenderung diletakan pada bidang memanjang. Makna-makna motif ini mengandung arti seperti kelemahlembutan, kekeluargaan, pelindung, dan sumber kehidupan.

\section{Motif Kaligrafi}

Motif kaligrafi merupakan pola gambar ragam hias yang berupa huruf- huruf arab yang berasal dari kitab suci Al-Quran, agama Islam. Agama Islam dianut oleh sebagian besar masyarakat Indonesia sehingga pengaruh Islam sangat menonjol. Motif kaligrafi merupakan bentuk huruf-huruf Arab dengan berbagai variasi, dibentuk menyerupai corak geometris, benda mati, alam, tumbuh-tumbuhan, hewan dan manusia yang dibuat dalam berbagai variasi ayat-ayat suci AlQuran. Ayat-ayat yang umumnya dipergunakan adalah Ayat Qursi, Fatihah, Surat Ikhlas, Asmaul Husna Allah, Allahu Akbar, Muhammad, Bismillahirrahmanirrahim, dan ayat- ayat lainnya.

\section{Motif Hewan (Fauna)}

Ragam hias motif fauna pada ukiran kayu Palembang sangat jarang ditemukan, karena pengaruh agama Islam yang kuat di Sumatera Selatan. Meskipun ada, pola gambar sudah distilasikan tidak menyerupai bentuk aslinya dan hanya bagian dari anatomi hewan yang disamarkan. Pengaruh ini merupakan dampak dari negara China, India, dan Eropa, motif fauna tersebut mengandung maksud perlambangan tertentu. Penggambaran hewan dalam ragam hias ukiran sebagian besar merupakan hasil stilirisasi, jarang berupa binatang secara natural, tapi hasil penyederhanaan tersebut masih mudah dikenali bentuk dan jenis binatangnya, bentuk binatang terkadang hanya diambil pada bagian tertentu dan dikombinasikan dengan motif lain.

\section{Bagian Struktur Ukiran Kayu Palembang}

Gaya motif ukiran kayu Palembang memiliki ciri 
khas yang berbeda dengan ukiran dari daerah lainnya. Keunikan tersebut berdasarkan bentuk, bahan, finishing dan teknik mengukir kayu tersebut, berikut ciri motif ukiran Palembang diambil dari isian ukiran bidang salah satu sisi lemari koleksi perajin Syarifudin di 19 Ilir Palembang dan tiang rumah tradisional Limas koleksi Museum Balaputra Dewa, sebagai berikut :

1. Secara umum bentuk pahatan ukiran Palembang termasuk berbentuk ukir sedang Mezzo Relief, ukir tinggi Haut Relief, ukir cekung Encreux Relief.

2. Angkup yang dimiliki ada tiga yaitu: pertama, angkup besar gubahan dari kuncup daun yang menelungkup pada daun pokok yang paling besar. Kedua, angkup sedang gubahan dari kuncup daun yang menelungkup pada daun berukuran sedang. Ketiga, angkup kecil gubahan dari kuncup daun yang menelungkup pada daun trubus yang berukuran kecil.

3. Cawen, pecahan pahatan berbentuk garis yang berjumlah 4 (rangkap 2 di setiap sisi daun), terdapat pada daun pokok dan daun patran.

4. Benangan, garis yang terdapat pada suluran berbentuk rendah ke dalam bidang.

5. Lung atau gelungan, bersusun tingkat atau putus dan ada yang saling menyambung.

6. Ceplok bunga, terdapat pada bagian atas daun pokok dan dominan diletakan di tengah secara simetris. Motif bunga dan buah yang sering dipakai pada ukiran kayu Palembang, yaitu bunga matahari, bunga mawar, bunga melati, bunga tanjung, bunga kundur, bunga cengkeh, dan kelopak manggis, buah mengkudu, buah nanas.

7. Daun pokok, terdapat gubahan daun membentuk ikal.

8. Daun Patran, uraian dari daun pokok yang berupa tumpal saling tumpang, pangkal daun patran berbentuk ikal/ulir bulat. Daun yang sering digunakan daun pakis berbentuk tumpal, pada ujung daun lancip dan mengecil.

9.Suluran akar atau batang berbentuk cembung memanjang dan menyambung, sedikit yang berbentuk cekung.

10. Ukiran motif hewan (fauna) sangat jarang ditemukan pada ukiran Palembang, meskipun ada bentuknya telah disamarkan karena merupakan akulturasi dari budaya luar daerah dan negara lain seperti China, India dan Eropa.

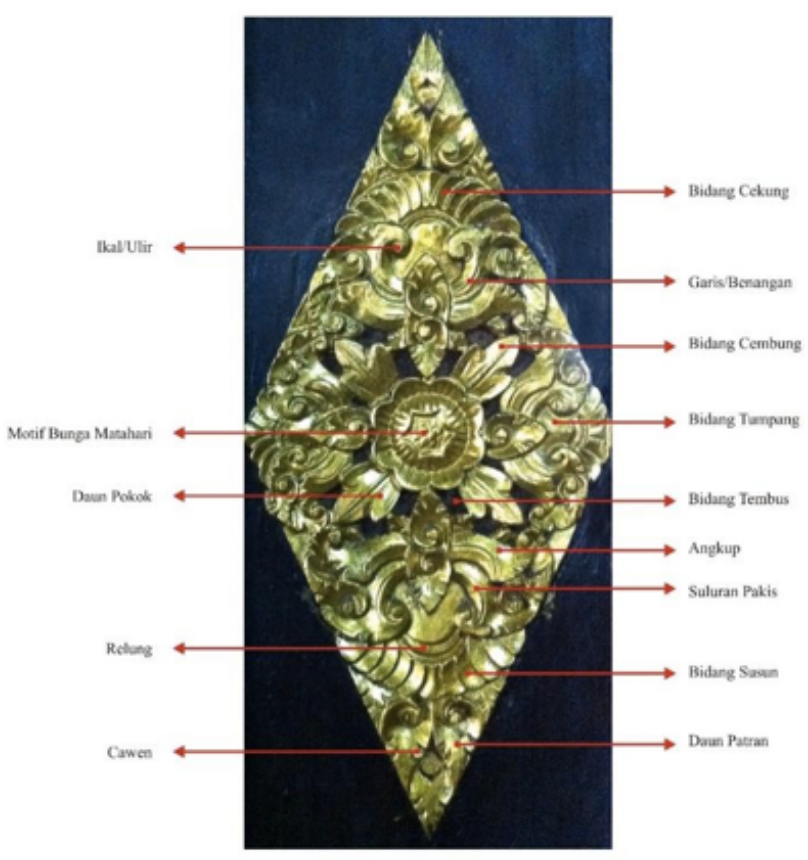

Gambar 3.

Bagian Struktur Ukiran Pada Tiang Rumah Limas Palembang. (Sumber Foto : Aji Windu Viatra, 2017).

11. Teknik pewarnaan ukiran diberi warna keemasan (perada emas) di atas warna tepak (merah manggis).

\section{Kontinuitas Seni Kerajinan Ukiran Kayu Palem- bang}

Keberadan seni kerajinan ukiran kayu Palembang telah menghadirkan warna baru di kehidupan sosial budaya masyarakat Palembang. Kegiatan mengukir telah dilakukan turun- temurun, dilakukan dengan penuh penjiwaan dan menjadi bagian hidup mereka, namun saat ini telah mengalami penurunan minat dikalangan generasi muda kota Palembang, yang tersisa hanya segelintir saja dari beberapa perajin ukiran tersebut, hal ini menyerupai fenomena pada era tahun 1950-1970an. Produk ukiran Palembang sangat bervariasi, baik jenis, ukuran, dan bahannya, serta mampu bersaing dengan daerah penghasil ukiran lainnya. Beberapa hasil produksi sudah memasuki pasar nasional dan internasional, bahkan terdapat juga para pembeli yang datang langsung ke lokasi para perajin ukiran di 19 Ilir Palembang.

Produk ukiran kayu Palembang memiliki perubahan bentuk sesuai permintaan pasar dan berubah fungsi sebagai benda pakai atau hiasan. Ada beberapa kendala yang cukup mendasar dalam memenuhi kondisi tersebut yakni permasalahan untuk menciptakan motif-motif ukiran baru dan kuantitas produk ukiran. Masyarakat perajin ukiran saat ini selalu berkeinginan melakukan eksperimen dan menciptakan motif-motif 
yang dapat menunjukan identitas Palembang, namun masih dibayangi oleh kekhawatiran tidak memiliki nilai jual di pasaran. Permintaan jumlah produk ukiran dalam skala besar, seringkali sulit untuk dipenuhi oleh para perajin, disebabkan sistem kerja tradisional yang memang membutuhkan waktu yang lama, 1 hingga 2 bulan untuk menyelesaikan produk ukiran seperti satu lemari, satu set meja dan kursi.

Perubahan yang paling dirasakan masyarakat dan perajin ukiran kayu di Palembang, ketika masuknya para perajin dari daerah Jawa seperti Jepara pada awal tahun 1990an. Saat itu perajin ukiran Palembang dan Jepara melakukan kerjasama dalam suatu proyek renovasi rumah tradisional di Palembang, setelah selesai para perajin daerah lain tersebut banyak mendapat pesanan dari masyarakat sekitar untuk membuat ukiran berupa perabotan rumah tangga, karena hal tersebut para perajin banyak mendapat penghasilan yang cukup sehingga para perajin melihat potensi yang cukup dapat memenuhi kebutuhan hidup mereka, hingga saat itulah para perajin ukiran Jepara mulai menetap tinggal di Palembang. Fenomena ini merupakan salah satu faktor yang memberikan peranan berarti untuk kontinuitas seni ukiran kayu Palembang.

Hasil dari berkembangnya seni ukiran kayu Palembang dapat dicermati melalui meningkatnya tingkat taraf kehidupan sosial, budaya, dan ekonomi masyarakat khususnya para perajin ukiran.

\section{Peranan Sosial Terhadap Kontinuitas Seni Kera- jinan Ukiran Kayu Palembang}

Perkembangan seni ukiran kayu Palembang, smakin berkembang mengikuti permintaan pasar dan berubah fungsi sebagai benda pakai atau hiasan. Seiring waktu, perubahan ini mendapatkan pengaruh yang datang dari dalam maupun luar sehingga berdampak makin berkembangnya bentuk, fungsi, teknologi, dan nilai estetiknya. Perubahan itu adalah inovasi gagasan dan nilai, teknik-teknik atau aplikasi baru dalam teknologi dan seni. Hal ini menjadikan masyarakat berusaha mengatasi permasalahan tersebut dengan upaya pengembangan dan menghadirkan inovasi baru secara kreatif, meskipun banyak terdapat perajin yang memilih mundur untuk mencari profesi lain.

Perkembangan seni tradisi ini tidak lepas dari perhatian dari pihak- pihak yang memiliki perhatian terhadap seni ukiran. Struktur sosial di masyarakat kota Palembang, seperti Pemerintah Daerah Kota Palembang, Disparbud, Disperindag, Bappeda, Dekarnas, Dewan Kesenian, Perguruan Tinggi, Praktisi Akademisi, Lembaga Masyarakat, Perusahaan, Seniman,
Tokoh Masyarakat, Perajin Ukiran, dan masyarakat Palembang harus selalu mengadakan program-program yang berkelanjutan. Pembinaan dan pelatihan yang pernah dilakukan seringkali mengalami hambatan yang cukup membuat berbagai pihak untuk lebih berusaha lebih keras lagi. Hambatan yang sering dijumpai seperti sumber daya manusia atau instruktur perajin ukiran lokal yang sangat terbatas, ketersediaan sarana teknologi yang kurang memadai, kurangnya minat generasi muda akan seni ukiran kayu tersebut, publikasi kegiatan yang tidak merata bagi berbagai pihak dalam struktur masyarakat sosial, program kegiatan yang tidak berkelanjutan, kurangnya rasa kebersamaan antara para perajin yang membuat sulit untuk dibentuk menjadi suatu komunitas atau kelompok. Namun hambatan-hambatan tersebut tidak menyurutkan niat baik dari berbagai pihak untuk mengembangkan dan melestarikan kebudayaan khususnya Kota Palembang.

\section{Peranan Budaya}

Perubahan signifikan dalam ukiran kayu Palembang saat masuknya budaya dari daerah dan negara luar. Hadirnya para perajin dari daerah Jawa seperti Jepara pada awal tahun 1990an, menjadi salah satu faktor yang memberikan perubahan terhadap munculnya berbagai variasi bentuk produk baru yang tidak dikenal sebelumnya dan bentuk baru yang berkelanjutan dari bentuk-bentuk sebelumnya.

Ketrampilan mengukir masyarakat Palembang selalu hadir ditengah kehidupan keluarga bermasyarakat. Warisan ilmu dan ketrampilan yang sudah menjadi bagian hidup, diturunkan dari generasi ke generasi berikutnya, terdapat juga minat, usaha keras dan semangat untuk belajar, amatir belajar melakukan hal yang benar, dan professional belajar untuk menjadi sempurna.

\section{Peranan Perajin Ukiran}

Perajin ukiran memiliki peran yang sangat penting untuk eksistensi seni tradisi ini. Kreatifitas perajin ukiran merupakan salah satu faktor terjadinya perubahan. Terdapat dua variabel sumber kreatifitas yaitu pengaruh lingkungan dan diri sendiri. Lingkungan alam dan budaya juga mempengaruhi kepekaan dalam mengolah bahan, warna, motif, fungsi dan nilai estetik menjadi suatu benda seni. Keahlian mengukir di Palembang banyak diperoleh melalui proses pembelajaran nonformal di dalam keluarga para perajin. Warisan keterampilan tersebut mempunyai arti sangat penting bagi kelangsungan dan perkembangan seni ukir Palembang. Dorongan-dorongan untuk membuat desain baru atau produk inovatif jelas dipengaruhi oleh lingkungan sekitar maupun 
latar belakang pribadi. Kemampuan dalam berkreasi perajin didasari oleh kemampuan keterampilan yang dimilikinya.

\section{Peranan Akademi Pendidikan}

Peranan akademi pendidikan menjadi salah satu sektor yang sangat menunjang bagi keberlangsungan ukiran Palembang. Peranan melalui program dan strategi kreatif, seperti mengadakan penelitian, analisis, penemuan baru, pembinaan dan workshop, dapat menambah nilai dalam pengembangan seni kerajinan ukiran Palembang. Program-program penelitian dan pengabdian masyarakat berupa penyuluhan, pendidikan dan pelatihan sangat jarang ditemui dalam masyarakat Palembang, meskipun sudah pernah dilakukan namun kurang memberikan dampak cukup berarti bagi masyarakat, hal ini pernah dilaksanakan dalam jangka waktu yang lama. Hal ini dijelaskan oleh para perajin ukiran, program terakhir yang pernah dilakukan adalah program pelatihan mengukir dan pembinaan peminjaman modal oleh Dinas Perindustrian Palembang pada tahun 2003, di Kelurahan 19 Ilir Palembang.

\section{Peranan Pemerintah}

Pemerintah memiliki peran yang besar dalam melindungi dan mengayomi terhadap seni-budaya bangsa. Pemerintah banyak melakukan pembinaan terutama dalam penerapan teknologi, manajemen, permodalan, dan pemasarannya. Perbaikan- perbaikan kualitas dan upaya pemenuhan kuantitas produk seni kerajinan ukiran kayu selalu diperjuangkan. Pemerintah melalui Depertemen perindustrian dan Perdagangan beberapa kali mengajak perajin ukiran untuk pameran di kota- kota besar Indonesia dan luar negeri. Perajin-perajin ukiran kayu mendapat pembelajaran langsung dari Departemen Perindustrian dan Perdagangan dalam upaya meningkatkan industri rakyat dan perekonomian kerakyatan. Lembaga- lembaga tersebut sangat membantu meningkatkan usaha ukiran kayu dengan memberikan bimbingan dan penyuluhan diberbagai segi ilmu seni ukir.

\section{Perubahan Seni Kerajinan Ukiran Kayu Palem-}

\section{bang}

Kontinuitas dan perubahan seni ukiran kayu Palembang yang terjadi dipengaruhi oleh berbagai faktor, yakni budaya, perajin ukiran, institusi-institusi pemerintah, lembaga akademi, dan perusahaan atau lembaga swasta. Perubahan seni kerajinan ukiran kayu terjadi pada bentuk, motif, ukuran, teknik, warna, bahan material, dan fungsi. Seni ukiran kayu Palembang telah mengalami perubahan baik dari ukuran media, bahan baku, fungsi dan ragam hias. Perubahan tersebut antara lain :

\section{Ukuran}

Perubahan ukuran ukiran kayu Palembang disetiap media yang ada saat ini, dilakukan oleh perajin merupakan bentuk pesanan dari konsumen, produk pesanan ukiran disesuaikan dengan kebutuhan bidang, ruang, dan tempat yang akan digunakan oleh konsumen. Media ukiran seperti lemari, meja, kursi, bangunan rumah di setiap bidang ruang pada umumnya mempunyai ukuran tertentu. Lemari dengan tipe 2 pintu, 3 pintu, dan 5 pintu sebelumnya ada yang berdiri secara tunggal dan menempel pada dinding rumah, lemari tunggal yang berukuran tinggi $230 \mathrm{~cm} \mathrm{x}$ lebar $200 \mathrm{~cm}$, dan 3 pintu, berubah saat ini menjadi tinggi $200 \mathrm{~cm}$ x lebar $180 \mathrm{~cm}$, dan 3 pintu, dan seringkali ukuran berubah berdasarkan pesanan dengan mengikuti ruang dan tempat. Lemari tempel saat ini sangat jarang ditemukan, karena pembangunan rumah tinggal masyarakat tidak banyak yang menggunakan rumah panggung lebih cenderung dengan gaya rumah modern (batu), sehingga kebutuhan lemari ukiran dengan ukuran besar tidak begitu banyak peminatnya.

\section{Bahan}

Seni kerajinan ukiran kayu Palembang memiliki hubungan erat dengan rumah tradisional adat Palembang, yakni rumah Bari atau rumah Limas. Rumah tradisional yang saat ini masih digunakan oleh masyarakat Sumatera Selatan, khususnya di Palembang dengan segala perlengkapan rumah tangganya. Aneka ragam perabotan yang ada berupa furniture atau alat-alat rumah tangga banyak yang terbuat dari kayu dengan ukirannya, dan berbagai peralatan yang kadang berfungsi sebagai hiasan rumah. Ukiran kayu Palembang dibuat dengan bahan baku dari kayu Ulin dan Tembesu berkualitas baik. Kelangkaan bahan baku yang berkualitas, menyebabkan para perajin gebyok mulai menggunakan bahan kayu alternatif dan kayu-kayu ulin, tembesu bekas yang berasal dari bongkaran rumah-rumah panggung masyarakat Palembang, hingga dari daerah lain di Sumatera Selatan. Penggunaan bahan baku alternatif tersebut menjadikan kualitas ukiran kayu Palembang menurun, dari segi kualitas produk ukiran dan harga jual.

\section{Fungsi}

Peranan fungsi seni ukiran Palembang, diuraikan Abdullah Saleh (1995), bahwa peranan ukiran kayu Palembang dibagi menjadi 2 bagian menurut fungsinya, yaitu fungsional konstruktif dan fungsional 
Tabel 1. Perubahan Seni Ukiran Kayu Palembang.

\begin{tabular}{|c|c|c|}
\hline Perubahan & Tahun 1970-1990 & Tahun 1990-2016 \\
\hline Bentuk & $\begin{array}{l}\text { Rumah, lemari, meja, kursi, } \\
\text { ranjang, mimbar masjid. }\end{array}$ & $\begin{array}{l}\text { Lemari, meja, kursi, ranjang, hiasan } \\
\text { dinding, lehar, pelaminan, tepak } \\
\text { pengantin, mimbar masjid, meja rias } \\
\text { kaca, rak lemari, panel pembatas } \\
\text { ruang, merchandise }\end{array}$ \\
\hline Ukuran & $\begin{array}{l}\text { Standar (Lemari, tinggi } 230 \mathrm{~cm} \mathrm{x} \\
\text { lebar } 200 \mathrm{~cm} \text {, dan } 3 \text { pintu) }\end{array}$ & $\begin{array}{l}\text { Tidak standar (Lemari, ukuran } \\
\text { disesuaikan ruang dan tempat) }\end{array}$ \\
\hline Motif & $\begin{array}{l}\text { Tumbuh- tumbuhan } \\
\text { Alam } \\
\text { Kaligrafi }\end{array}$ & $\begin{array}{l}\text { Tumbuh- tumbuhan } \\
\text { Hewan } \\
\text { Alam }\end{array}$ \\
\hline Warna & Merah & Merah \\
\hline Teknik & Manual & $\begin{array}{l}\text { Manual } \\
\text { Mesin }\end{array}$ \\
\hline Fungsi & $\begin{array}{l}\text { Konstruksi } \\
\text { Estetika }\end{array}$ & Estetika \\
\hline Bahan & $\begin{array}{l}\text { Kayu Ulin } \\
\text { Kayu Tembesu } \\
\text { Kayu Medang } \\
\text { Kayu Merawan }\end{array}$ & $\begin{array}{l}\text { Kayu Tembesu } \\
\text { Kayu Medang } \\
\text { Kayu Merawan } \\
\text { Kayu Sungkai } \\
\text { Kayu Jati }\end{array}$ \\
\hline
\end{tabular}

aestetis. Ukiran fungsional konstruktif adalah ukiran yang bersifat aktif sebagai bagian daripada konstruksi bangunan atau barang yang dihias dengan ukiran. Ukiran fungsional aestetis bersifat pasif, tidak mempengaruhi konstruksi, media ukiran sebagai hiasan memperindah benda saja. Sekarang banyak dijumpai produk ukiran yang ditempatkan sebagai elemen aestetik di rumah tinggal, bahkan masjid. Fungsi utama ukiran sebagai bagian konstruksi juga berubah menjadi elemen estetik atau unsur dekoratif ruang rumah dan ruang publik.

\section{Ragam Hias}

Ragam hias ukiran kayu Palembang memiliki keunikan tersendiri dibandingkan dengan motif ukiran dari daerah lain. Bentuk ukiran yang rapi, rinci, dan detail dengan ukuran yang cukup kecil. Perwujudan ragam hias pada segala jenis produk ukiran mengalami perubahan, terdapat penyederhanaan bentuk motif ragam hias, dan pengurangan unsur-unsur hias pada ragam hias. Perubahan ragam hias tersebut akan mengurangi nilai dan makna yang ada. Dan juga perubahan ragam hias setelah hadirnya gabungan pola gambar motif dari daerah dan negara luar.

\section{Perencanaan Pengembangan Seni Kerajinan}

\section{Ukiran Kayu Palembang}

Suatu perencanaan dalam mengembangan ide dan gagasan untuk menciptakan produk-produk kerajinan yang bermutu dan berkualitas tinggi, dapat dilakukan dengan menciptakan langkah-langkah seperti berikut, yakni mementingkan pembangunan industri kreatif, meningkatkan kemampuan dan bakat dalam bersaing di era globalisasi saat ini, keterlibatan dari pihak-pihak yang terkait dan instansi pemerintah khususnya dalam mendukung pendanaan, investasi, perlindungan hak cipta, dan menjalin ikatan komunikasi para pelaku industri kreatif, serta membangun citra atau branding hasil karya anak bangsa. Industri kreatif memiliki peran cukup signifikan dalam mengembangkan perekonomian masyarakat, dalam hal ini industri kreatif berkontribusi penting bagi ekonomi, menciptakan iklim bisnis positif, memperkuat citra dan identitas bangsa Indonesia, pemanfaatann sumber daya terbarukan, selalu berinovasi dan kreatifitas. Program ini penting untuk dikembangkan dengan konsep yang baik, benar, efesien, efektif, dan detail.

Strategi pengembangan kerajinan ukiran kayu Palembang memerlukan langkah-langkah tepat dan metode-metode kreatif agar keutuhan seni tradisi tersebut tidak terkikis oleh waktu dan jaman. 
Langkah-langkah dalam membangun kontinuitas seni kerajinan ukiran kayu Palembang, antara lain : mengadakan sosialisasi pendidikan dan pelatihan secara rutin bagi masyarakat terutama usia produktif, mengenalkan seni kerajinan ukiran kayu bagi generasi penerus bangsa, membangun lingkungan yang kondusif dalam upaya mendukung bisnis kerajinan ukiran kayu, membranding dan mempromosikan ukiran kayu Palembang dalam area pangsa pasar domestik dan internasional, saling berkoordinasi antara pemerintah, instansi, perusahaan, institusi akademik, pengusaha dan perajin ukiran, serta masyarakat kota Palembang. Upaya yang dilakukan secara kontinyu melalui peningkatan ketrampilan, kreativitas perajin, dan meningkatkan akses pemasaran produk kerajinan.

Industri kerajinan merupakan industri yang potensial dalam peningkatan perekonomian masyarakat melalui perekonomian kreatif. Oleh karena itu diperlukan strategi pengembangan yang lebih baik yang dilakukan oleh pemerintah, perguruan tinggi dan pihak swasta agar potensi tersebut dapat dikembangkan lebih maksimal. Faktor-faktor yang mendukung pengembangan industri kerajinan tiap-tiap daerah akan berbeda-beda, oleh karena itu diperlukan pembenahan sehingga faktor-faktor pendukung pengembangan industri kerajinan dapat berperan optimal dengan berbasis pada aspek nilai-nilai kearifan lokal.

\section{SIMPULAN DAN SARAN}

\section{Simpulan}

Masyarakat Palembang dalam memenuhi kebutuhan hidupnya memanfaatkan lingkungan disekitarnya, sehingga memunculkan aktifitas budaya dengan menciptakan kreasi sandang dan pangan. Pemanfaatan lingkungan tersebut dapat dilihat dari sumber daya alam Propinsi Sumatera Selatan yang memiliki kekayaan alam berupa pertanian, pertambangan, perhutanan, perikanan, dan perkebunan. Lingkungan dibidang perhutanan menghasilkan area hutan yang cukup luas dengan menghasilan kayu-kayu berkualitas yang terdiri dari berbagai jenis pohon, seperi pohon ulin, tembesu, medang, meranti, merawan, dan leban, sehingga pemanfaatan hasil kayu digunakan secara berkelanjutan untuk memenuhi kebutuhan hidup sandang dan pangan.

Kegiatan mengukir di Palembang sebelumnya memiliki hubungan erat dengan rumah tradisional adat Palembang, yakni rumah Bari atau rumah Limas. Rumah tradisional yang saat ini masih digunakan oleh masyarakat Sumatera Selatan, khususnya di Palembang dengan segala perlengkapan rumah tangganya. Aneka ragam perabotan yang ada berupa furniture atau alat-alat rumah tangga banyak yang terbuat dari kayu dengan ukirannya, dan berbagai peralatan yang kadang berfungsi sebagai hiasan rumah. Aktifitas seni kerajinan ukiran kayu ini telah menjadi warisan budaya dalam kehidupan dalam masyarakat Sumatera Selatan. Perkembangan dan penyebaran seni tradisi ukiran ini tidak hanya berkisar di 19 Ilir yang sebagai sentra industri kerajinan ukiran kota Palembang saja, saat ini kegiatan ukiran sudah banyak menyebar di berbagai kecamatan, seperti: Ulu I, Ulu II, Ilir Barat I, dan Ilir Barat II.

Pertumbuhan ukiran kayu Palembang mengalami pasang surut dengan kondisi sosial dan ekonomi di wilayah tersebut. Menurut para perajin, kerajinan ukiran kayu ini hanya diproduksi oleh keluarga-keluarga tertentu saja, masih banyak masyarakat Palembang dan para perajin beralih mengandalkan penghasilan ekonomi dengan mencari profesi lain. Meskipun tingginya permintaan akan kebutuhan produk ukiran kayu tersebut tidak menjadikan suatu penghasilan meningkat yang dapat memuaskan kebutuhan perekonomian masyarakat perajin ukiran. Para perajin ukiran banyak yang memproduksi ukiran sesuai dengan pesanan dari kota Palembang dan daerah sekitarnya. Jumlah produk ukiran yang sangat terbatas menjadi salah satu kendala dalam memenuhi permintaan konsumen. Salah satu penyebabnya adalah proses pembuatan ukiran yang membutuhkan waktu yang lama antara 1-2 bulan, dan sistem kerja yang kolektif dalam proses mengukir memerlukan waktu saling menunggu di antara para perajin. Para perajin ukiran Palembang hanya mengandalkan pesanan yang datang, baru kemudian memproduksi produk ukiran, jika tidak ada pesanan mereka pun menganggur kembali, keterbatasan modal menjadi salah satu kendala dalam mengembangkan seni tradisi tersebut, baik dari bahan, teknik dan ragam hias ukiran.

Perubahan seni ukiran kayu Palembang saat ini berbeda dengan umumnya ukiran tradisional dari daerah lain. Perubahan yang terjadi pada proses pengolahan bahan kayu yang semakin sulit digunakan, cenderung menggunakan alternatif kayu lain, dan kayu bekas dari rumah-rumah panggung. Perubahan kreasi motif ukiran, jika sebelumnya motif ukiran sangat detail saat ini dimodifikasi lebih sederhana dengan tujuan efektif dan efisien. Teknik pengukiran telah bercampur dengan teknik mengukir dari daerah lain seperti Jepara, dan negara luar India, Eropa dan China. Akulturasi ragam hias ini telah menghasilkan suatu bentuk, gaya dan cita rasa baru menambah khasanah ukiran kayu Palembang.

Ragam hias ukiran dalam produk ukiran Palembang masih banyak yang memakai motif-motif lama atau sesuai dengan tradisi Palembang, seperti ukiran mo- 
tif bunga matahari, mawar, dan teratai. Perubahan penggunaan motif yang telah dimodifikasi secara sederhana ini disebabkan kebiasaan para perajin mengukir berdasarkan pesanan. Pola pikir dalam memahami nilai dan makna ukiran kurang begitu menjadi daya tarik bagi para perajin, hanya keahlian dan kemampuan mengukir secara teknis yang menjadi kekuatan mereka. Hal ini menjadi salah satu perhatian khusus bagi perkembangan seni kerajinan ukiran kayu di masyarakat Palembang.

\section{Saran}

Seni kerajinan ukiran kayu Palembang memiliki potensi besar dan bernilai tinggi bagi kemajuan masyarakat Palembang dan sekitarnya. Ragam hias ukiran Palembang tidak hanya dipandang dari segi keahlian teknis mengukirnya saja, diiringi juga dengan kemampuan merancangan motif-motif ukiran baru, sehingga dapat berkembang dan menghasilkan ciri khas ukiran yang berasal dari kota Palembang. Suatu metode perancangan ragam hias ukiran yang baru, sederhana, dan mudah untuk dipelajari, diharapkan mampu memberikan perubahan dan kemajuan dalam industri seni kerajinan masyarakat Palembang dan sekitarnya. Ide atau gagasan yang dapat diungkapkan untuk menjadi inspirasi dalam perancangan motif-motif ukiran yang baru, dapat berasal dari alam, lingkungan, sosial budaya masyarakat Palembang, seperti cerita rakyat, kondisi lingkungan geografis, sumber kekayaan flora, dan fauna.

Strategi pengembangan kerajinan ukiran kayu Palembang memerlukan langkah-langkah tepat dan metode-metode kreatif agar keutuhan seni tradisi tersebut tidak terkikis oleh waktu dan jaman. Suatu perencanaan dalam mengembangan ide dan gagasan untuk menciptakan produk-produk kerajinan yang bermutu dan berkualitas tinggi, dapat dilakukan dengan menciptakan langkah-langkah seperti berikut, yakni mementingkan pembangunan industri kreatif, meningkatkan kemampuan dan bakat dalam beraing di era globalisasi saat ini, keterlibatan dari pihak-pihak yang terkait dan instansi pemerintah khususnya dalam mendukung pendanaan, investasi, perlindungan hak cipta, dan menjalin ikatan komunikasi para pelaku industri kreatif, serta membangun citra atau branding hasil karya anak bangsa.

Pengkajian seni ukiran kayu Palembang masih perlu dilakukan secara mendalam, pentingnya manfaat dalam meningkatkan keahlian merancang ragam hias dengan unsur- unsur budaya lokal serta dapat diaplikasikan ke berbagai media, hal ini akan memberikan perkembangan dan peningkatan taraf hidup yang lebih baik bagi masyarakat para perajin ukiran, dan masyarakat Sumatera Selatan.

\section{DAFTAR RUJUKAN}

A.A. Navis. 1984. Alam Takambang Jadi Guru. Grafiti Press, Jakarta.

Bustomi, Suwaji. 2003. Seni Kriya. UNNES Press, Semarang.

Bastomi, Suwaji. 1986. Seni Ukir. IKIP Semarang, Semarang.

Gustami, SP. 2000. Seni Kerajinan Mebel Ukir Jepara. Penerbit Kanisius, Yogyakarta.

Kartini, Ayu. 2014. Analisis Penerapan Ornamen Bernuansa Melayu Ditinjau Dari Bentuk Dan Warna Di Kota Medan. Jurusan Pendidikan Seni Rupa, Fakultas Bahasa Dan Seni, Universitas Negeri Medan.

Saleh, Abdullah. Indrajaya. Ayub, Mahidin. Adiel, Marah. 1996. Diskripsi Seni Ukir Palembang Dan Sekitarnya. Departemen Pendidikan dan Kebudayaan Sumatera Selatan.

Sukanti, Zulbiati dan Emawati. 2012. Rumah Ulu Sumatera Selatan. Museum Negeri Propinsi Sumatera Selatan Balaputra Dewa, Palembang.

Sunaryo. Aryo. 2009. Ornamen Nusantara. Dahara Prize, Semarang.

Soedarso, Sp. 2006, Trilogi Seni, Institut Seni Indonesia Yogyakarta: Yogyakarta.

Soedarso, R.M. 1999. Metodologi Penelitian Seni Pertunjukan dan Seni Rupa. Bandung.

Wahono, ir, Ym Kussunartini, Sunarto madenur budi santosa, s.sos. rohayati. 2005. Ragam Hias Ukir Kayu. Pemerintah Provinsi Jawa Tengah Dinas Pendidikan dan Kebudayaan, Museum Jawa Tengah Ronggowarsito, Semarang.

William, Raymond. 1981, Culture. Fortana Paperback, Glasgow.

Jurnal "Ekspresi Seni", (Vol. 16, No. 1, Juni 2014). Nofrial, "Ukiran Akar Kayu Pulau Betung Jambi Menuju Industri Kreatif", Institut Seni Indonesia Padangpanjang.

Disertasi, Ni Putu Nina Eka Lestari, (2014), "Strategi Pemberdayaan Industri Kecil Kerajinan Ukiran Kayu Di Kabupaten Gianyar Provinsi Bali", Program Doktor, Program Studi Ilmu Ekonomi, Program Pascasarjana, Universitas Udayana, Denpasar 
Narasumber :

Drs. Ambrizal, (57 thn), Budayawan dan Guru, wawancara tanggal 4 April 2017 di Palembang, Sumatera Selatan.

Agus Anwar, (52 thn), Perajin Ukiran Kayu, wawancara tanggal 26 Mei 2017 di Sentra Industri Ukiran 19 Ilir Palembang, Sumatera Selatan.

Syarifuddin, (64 thn), Perajin Ukiran Kayu, wawancara tanggal 5 Juni 2017 di Sentra Industri Ukiran 19 Ilir Palembang, Sumatera Selatan.

M. Soleh, (35 thn), Perajin Ukiran Kayu, wawancara tanggal 7 Juni 2017 di Sentra Industri Ukiran 19 Ilir Palembang, Sumatera Selatan.

A. Rafanie, (60 thn), Budayawan, wawancara tanggal 10 Juli 2017 di Bidang Sejarah dan Purbakala, Dinas Pariwisata dan Kebudayaan Sumatera Selatan.

Ribuanata, (56 thn), Budayawan, wawancara tanggal 14 Juli 2017 di Museum Negeri Balaputra Dewa, Palembang, Sumatera Selatan. 